Original Article

\title{
THE BENEFICIAL EFFECT OF 20\% SUNFLOWER SEED OIL CREAM ON MILD ATOPIC DERMATITIS IN CHILDREN
}

\section{REIVA FARAH DWIYANA, HARTATI PURBO DARMADJI, RISA MILIAWATI NURUL HIDAYAH, FITRA HERGYANA, SRIE PRIHIANTINI GONDOKARYONO, INNE ARLINE DIANA, CATHERINA JESSICA SUTANTOYO, HENDRA GUNAWAN*}

Department of Dermatology and Venereology, Faculty of Medicine, Universitas Padjadjaran-Dr. Hasan Sadikin Hospital, Pasteur 38, Bandung, West Java 40161, Indonesia

Email: enda.guna@yahoo.com

Received: 09 Nov 2018 Revised and Accepted: 05 Jan 2019

ABSTRACT

Objective: The objective of this study was to evaluate the beneficial effect of topical applications of $20 \%$ sunflower seed oil (SSO) in decreasing the transepidermal water loss (TEWL) and scoring of atopic dermatitis (SCORAD) index value in mild atopic dermatitis (AD) pediatric patients in Bandung, Indonesia.

Methods: This was a randomized study involving 20 children with mild AD (SCORAD $<25$ ) in Bandung, Indonesia. They were divided into 2 groups: the experimental group treated with $20 \%$ SSO cream and the control group treated with a common moisturizing cream for four weeks. The TEWL score including SCORAD index was evaluated at baseline, week 1, week 2, and week 4.

Results: A total of 20 participants completed the study. In the first week, the control group had TEWL score decrement by $36.62 \%$ while the experimental group by $28.89 \%(p=0.88)$. In the fourth week, the TEWL decrements of the experimental and control group were by $56.94 \%$ and $52.50 \%$, respectively $(p=0.20)$, and this was followed by an improvement of SCORAD index in both treatment groups.

Conclusion: The 20\% SSO cream has a beneficial effect in decreasing the TEWL score and improving SCORAD indices. Therefore, it can be considered as an alternative treatment for mild AD among children.

Keywords: Atopic dermatitis, Moisturizer, Sunflower seed oil, Transepidermal water loss

(C) 2019 The Authors. Published by Innovare Academic Sciences Pvt Ltd. This is an open access article under the CC BY license (http://creativecommons.org/licenses/by/4.0/) DOI: http://dx.doi.org/10.22159/ijpps.2019v11i2.30707

\section{INTRODUCTION}

Atopic dermatitis (AD) is an inflammatory skin condition characterized by intense pruritus in a waxing and waning course [1] It affects $10-20 \%$ children and $1-3 \%$ adults worldwide, with a female to male ratio of 1.3:1.1 [1]. In 2013, the prevalence of AD according to Pediatric Dermatology Clinic data from five tertiary referral hospitals in Indonesia was 11.8\% [2].

A complex interaction between genetic, immune system dysregulation and environmental factors have been documented as the pathogenesis of $\mathrm{AD}[2]$. Filagrin mutation decreased ceramide, and increased endogenous proteolytic enzymes, often result in increased transepidermal water loss (TEWL) [3]. In the case of a damaged skin barrier function, TEWL normally increases and facilitates the penetration of allergens and microbes into the skin [4]. Jensen et al. reported an increase of TEWL in AD patients, both in the lesional and non-lesional skin [5]. Scoring of atopic dermatitis (SCORAD) is a clinical tool used to assess the extent and severity of $\mathrm{AD}$, which can be used before and after treatment to determine its effectiveness. It measures the of the extent of skin lesions, the intensity of the disease, and subjective complaints [6].

Natural moisturizing factor (NMF) deficiency has been observed in AD patient's skin. Natural moisturizing factor (NMF) maintains the TEWL in the stratum corneum by serving as humectant [7]. Peroxisome proliferator-activated receptor-alpha (PPAR- $\alpha$ ) might improve skin barrier function by regulating the lipid metabolism in the skin and stimulating keratinocyte differentiation, whose expression was usually reduced in $\mathrm{AD}[8$ 9]. The use of moisturizer in $\mathrm{AD}$ patients may improve the function of the skin barrier [10]. Nevertheless, its high cost can be a burden for low-income society. Therefore, an effective and cost-effective moisturizer, like sunflower seed oil (SSO) cream, is urgently needed.
Sunflower (Helianthus annus) seeds have been found to contain carbohydrates, proteins, fats, calcium, flavonoids, alkaloids, and many other phytochemicals which are responsible for their beneficial pharmacological properties [11]. Sunflower seed oil (SSO) is an oil produced from these seeds, contains a high level of essential fatty acids, especially linoleic acid, which improves the skin barrier and thus frequently used in infant skin care [12]. It is affordable, safe, and attainable in Indonesia. Various studies on SSO have shown that it has a virtuous effect in patients with normal skin as well as in AD patients $[12,14]$. SSO exerts its anti-inflammatory effect by binding with PPAR receptor in the surface of keratinocytes $[15,16]$. Various studies on SSO in both AD and non-AD child population have given evidence of its effectiveness in lowering the TEWL scores [14 15]. However, to the best of the authors' knowledge, there has been no study comparing SSO with common moisturizers.

Table 1: $20 \%$ SSO cream formula

\begin{tabular}{l}
\hline 20\% SSO cream formula \\
\hline Refined $20 \%$ sunflower seed oil \\
Cetostearyl alcohol $10 \%$ \\
Cetomacrogol $10 \%$ \\
Petroleum jelly $5 \%$ \\
Potassium sorbate $0.1 \%$ \\
Propilen glycol $7.5 \%$ \\
Citrus fragrance qs \\
Aquadest ad 100 gr \\
\hline
\end{tabular}

\section{MATERIALS AND METHODS}

Material and preparation of drugs

The $20 \%$ SSO cream used in this study was made by pharmacists in Bandung Institute of Technology, Indonesia and had undergone 
product animal testing prior to the experiment. The formula is presented in table 1 . Meanwhile, the control product cream was common moisturizing lotions, which were repackaged in uniform opaque plastic pots.

\section{Study design}

This randomized, double-blind trial, in children with mild AD, was conducted in two locations: in the outpatient clinic of Dermatology Department in Dr. Hasan Sadikin Hospital Bandung and Sejahtera Elementary School Bandung. This study had been approved by the Health Research Ethics Committee, Faculty of Medicine, Universitas Padjadjaran/Dr. Hasan Sadikin Hospital Bandung, West Java, Indonesia with ethical clearance number: LB.04.01/A05/EC/296/IX/2016. Informed consent from one parent or caregiver and the assent of children were likewise secured prior to treatment.

\section{Subject}

The enrolled participants were those patients in the age range of 7$12 \mathrm{y}$ of age with mild AD, who met the Hanifin and Rajka criteria and had SCORAD index of $<25$, were enrolled. The exclusion criteria were: (1) those with known hypersensitivity reactions to SSO cream and control product cream, (2) those who have used moisturizer other than the given treatment or any medication on both arms, legs, and lesions within one week prior to the study, (3) those who have taken anti-inflammatory and antihistamine drugs $2 \mathrm{w}$ before and during the study, (4) those with other co-existing another skin diseases in the area that were going to be treated, (5) those with coexisting recurrent atopic disease, (6) those who had AD with secondary bacterial infection.

\section{Procedures}

Twenty children with $\mathrm{AD}$ who met the criteria were randomly assigned into two groups: group I ( 9 participants) who were treated with $20 \%$ SSO cream and group II (11 participants) who were treated with a common commercial moisturizer. Both creams passed the animal testing and were repacked in an opaque container. They were marked with random labels and only research assistant knew the contents of each label. Both researchers and subjects of the study were blinded to the content of the creams. TEWL was measured on the mid-volar of the lower arm, both popliteal fossa, and skin lesions. The cream was then applied on both arms, both limbs, and in AD lesions (if present). Patient-applied the cream twice daily at home in the same instructed locations. No other creams or lotions may be used on the observation area. Clinical assessments were performed at baseline (day 0), and on follow up on week 1 (day 7), week 2 (day 14 ), and week 4 (day 28).

\section{Outcome measures}

The TEWL score was measured at baseline, week 1, week 2, and week 4 using the Tewameter TM $300^{\circledR}$ at four regions (head/neck, trunk, upper and lower limbs). On each visit, patients were observed for any adverse effect, which, if found, would be recorded. The SCORAD index was measured at every visit.

\section{Statistical methods}

Paired t-test was used to compare the TEWL scores. Meanwhile, the Mann-Whitney test was used to compare the mean of the TEWL scores and SCORAD index between the two groups. Results were considered to be significant if the p-value was less than 0.05 .

\section{RESULTS \\ Demographic profile}

In both groups, the age ranges from 7 to $12 \mathrm{y}$ old. The mean age for SSO cream group and control cream group were $8.56 \pm 1.51 \mathrm{y}$ and $9.45 \pm 2.70$ y respectively. Sixty-five percents (13 out of 20 ) of the patients were female.

Table 2: Demographic data in both groups

\begin{tabular}{llll}
\hline Variables & SSO 20\% & Control cream & p-value \\
\cline { 2 - 3 } & $\mathbf{( n = 9 )}$ & $\mathbf{( n = 1 1 )}$ & $0.38^{*}$ \\
\hline Age (years) & $7-11$ & $7-12$ & $0.160^{* *}$ \\
Mean age (years) & 8.56 & 9.45 & \\
Sex & 5 & 2 & \\
Male & 4 & 9 & \\
Female & & & \\
\hline
\end{tabular}

${ }^{*}$ p-value $>0.05$ compared with the control group using paired t-test., ${ }^{* *}$-value $>0.05$ compared with the control group using fisher's exact test.

\section{TEWL scores}

The TEWL scores in both treatment groups were measured on the right arm, left arm, right leg, and left leg. There was a reduction of TEWL scores in both treatment groups. The average TEWL score was 17.26 in SSO cream group and 16.31 in the control cream group at baseline; 12.26 in the SSO cream group and 10.32 in control cream group on week $1 ; 8.93$ in the SSO cream group and 8.69 in the control cream group on week 2; 6.67 in the SSO cream group and 7.74 in the control cream group on week 4 , as presented in table 3 . The paired t-test showed that TEWL scores did not differ significantly between both groups at baseline $(\mathrm{p}=0.827)$, week $1(\mathrm{p}=0.481)$, week $2(\mathrm{p}=0.899)$, and week $4(\mathrm{p}=0.472)$.

Table 3: Average of TEWL Scores after the application of SSO cream and control product cream

\begin{tabular}{|c|c|c|c|c|c|}
\hline \multirow[t]{2}{*}{ Group } & \multirow[t]{2}{*}{ Location } & \multicolumn{4}{|l|}{ Time } \\
\hline & & Baseline & Week 1 & Week 2 & Week 4 \\
\hline \multirow[t]{5}{*}{ SSO cream } & Right arm & 18.05 & 13.27 & 9.01 & 6.96 \\
\hline & Left arm & 17.68 & 13.88 & 9.95 & 7.36 \\
\hline & Right leg & 16.42 & 10.84 & 7.87 & 6.06 \\
\hline & Left leg & 16.87 & 11.06 & 8.89 & 6.27 \\
\hline & Mean & 17.26 & 12.26 & 8.93 & 6.67 \\
\hline \multirow[t]{5}{*}{ Control } & Right arm & 17.23 & 11.17 & 9.17 & 8.39 \\
\hline & Left arm & 18.02 & 10.39 & 9.21 & 8.63 \\
\hline & Right leg & 15.74 & 10.18 & 8.23 & 7.07 \\
\hline & Left leg & 14.23 & 9.56 & 8.15 & 6.88 \\
\hline & Mean & 16.31 & 10.32 & 8.69 & 7.74 \\
\hline p-value & & $0.827^{* *}$ & $0.481^{* *}$ & $0.899^{* *}$ & $0.472^{* *}$ \\
\hline
\end{tabular}

${ }^{* *}$ p-value $>0.05$ compared with the control group using paired t-test 


\section{TEWL scores decrement}

The TEWL score decrement $(\Delta)$ was measured from four different locations. The average TEWL scores decrement $(\Delta)$ was 4.98 in the SSO cream group and 5.97 in the control cream group after $1 \mathrm{w}$; 8.45 in the SSO cream group and 7.61 in the control cream group after $2 \mathrm{w} ; 9.83$ in the SSO cream group and 8.56 in the control cream group after $4 \mathrm{w}$ as presented in table 4 . The Mann Whitney test showed that the average TEWL score decrement was not significantly different between both groups after $1 \mathrm{w}(\mathrm{p}=0.882)$, after $2 \mathrm{w}(\mathrm{p}=0.882)$, and after $4 \mathrm{w}$ $(\mathrm{p}=0.2052)$.

Table 4: Average TEWL Scores after application of SSO cream and control product cream

\begin{tabular}{|c|c|c|c|}
\hline \multirow[t]{2}{*}{ Group } & \multicolumn{3}{|l|}{ Timeline } \\
\hline & $\Delta$ Baseline- week 1 & $\Delta$ Baseline-week 2 & $\Delta$ Baseline- week 4 \\
\hline SSO $20 \%$ & 4.98 & 8.45 & 9.83 \\
\hline Control & 5.97 & 7.61 & 8.56 \\
\hline P-value & $0.882^{* *}$ & $0.882^{* *}$ & $0.941^{* *}$ \\
\hline
\end{tabular}

**p-value $>0.05$ compared with the control group using Mann-Whitney test.

\section{Scorad}

A trend of decreasing SCORAD index was observed in both groups throughout the treatment session. Reductions of the SCORAD index were $100 \%$ in both groups. The SCORAD indices in the SSO cream group were $7.23,2.45,0.61$, and 0 , whereas in the control cream group were $9.33,4.36,1.87$, and 0 on the baseline, week 1 , week 2 , and week 4, respectively. This considerable improvement in SCORAD index was observed in both groups, as presented in table 5 .

Table 5: Mean SCORAD among SSO 20\% dan control group

\begin{tabular}{lllll}
\hline Group & Time & Week 2 & \\
\cline { 2 - 4 } & Baseline & Week 1 & 0.61 & Week 4 \\
\hline 20\% SSO & 7.23 & 2.45 & 1.87 & 0 \\
Control & 9.33 & 4.36 & $0.131^{* *}$ & 1.000 \\
p-value & 0.456 & $0.412^{* *}$ & 0 \\
\hline
\end{tabular}

**p-value $>0.05$ compared with the control group using Mann-Whitney test

\section{Adverse effects}

There were no adverse reactions reported by either both groups in this study.

\section{DISCUSSION}

The clinical manifestation of $\mathrm{AD}$ appeared at the age of 6 mo in fortyfive percent of cases, and about eighty-five percent of AD cases were found before the age of 5 y [9]. In this study, the age of the participants with mild AD ranged from 2-12 y old, and the mean age was $8.56 \pm 1.51 \mathrm{y}$ in the SSO cream group, and $9.45 \pm 2.70 \mathrm{y}$ in the control cream group. Resecach showed that AD is slightly more common in women than in men with 1.3:1.0 ratio [13]. In this study, there were 13 girls (65\%) and 7 boys (35\%) with a ratio of 1.85:1.0. This ratio is consistent with worldwide prevalence [1].

Sunflower seed oil is an occlusive moisturizer and has emollient properties [15]. It has a high content of essential fatty acids (EFA), especially linoleic acid which could increase the skin barrier [16-18]. Linoleic acid content in SSO can be converted into arachidonic acid, a precursor of prostaglandin E2 (PGE2), which is a known modulator of cutaneous inflammation [12]. In human keratinocytes, PPAR- $\alpha$ activators, including linoleic acid, have a regulatory effect by increasing involucrin and transglutaminase protein $[15,16]$.

The effect of SSO cream in decreasing TEWL was demonstrated in previous randomized controlled trials, and it was postulated to have anti-inflammatory activity, making it an effective treatment to $\mathrm{AD}$ [13]. Study done by Danby et al. (2012) revealed that SSO can maintain the integrity of the stratum corneum, repair the skin barrier, and decrease the TEWL value [14]. This was confirmed by Husna's study (2012), which revealed that SSO application on the adult forearm could reduce the TEWL value [19].

In this present study, the efficacy of $20 \%$ SSO cream as a moisturizer to treat mild AD was compared with the control product as indicated by the decrement of TEWL and SCORAD score decrement. Both groups demonstrated a decreasing trend in both TEWL and SCORAD indices (table 4 and 5). Twenty percent of SSO cream decreased
TEWL score by $28.89 \%, 48.99 \%$, and $56.94 \%$ in week 1 , 2, and 4 respectively. On the other hand, control product cream decreased TEWL score by $36.62 \%$ on week $1,46.68 \%$ in week 2 and $52.54 \%$ at the end of the study period. Statistical analysis showed that the average TEWL score decrement was not significantly different between both groups. In the SSO 20\% cream group, the SCORAD indices plummeted from 7.23 (baseline) to 0 (week 4), whereas in the controlled group, from 9.33 (baseline) to 0 (week 4). These results showed that the ability of $20 \%$ SSO cream to decrease TEWL and improve SCORAD indices is comparable with the control product cream in treating mild cases of $\mathrm{AD}$. The limitation of this study was the relatively short follow-up time $(4 \mathrm{w})$, which may not be able to observe late adverse effects of $20 \%$ SSO cream as a moisturizer.

\section{CONCLUSION}

Twenty percent SSO cream has a comparable efficacy compared with the control product in decreasing the TEWL and SCORAD index among children with mild AD. Further studies with larger samples are required, but this study demonstrated that $20 \%$ SSO cream can be considered as an alternative moisturizer in the treatment of mild $\mathrm{AD}$ due to its low cost, beneficial effect, and minimal side-effect.

\section{ACKNOWLEDGMENT}

The authors are grateful to Universitas Padjadjaran, Bandung, Indonesia for financial support. (Grant number: 2924/UNG. $\mathrm{C} / \mathrm{HK} / 2014)$. The authors are also thankful to the authority of Department of Dermatology and Veneorology, Universitas Padjadjaran, Bandung, Dr. Hasan Sadikin hospital for affording necessary facilities.

\section{AUTHORS CONTRIBUTIONS}

Designed the experiments: Hartati Purbo Dharmadji, MD, Risa Miliawati, MD, Fitra Hergyana, MD, Reiva Farah Dwiyana, MD, MSc, Srie Prihianti Gondokaryono, MD, PhD, Inne Arline Diana, MD, Hendra Gunawan, MD, PhD. Performed the experiments: Hartati Purbo Dharmadji, MD, Risa Miliawati, MD, Fitra Hergyana, MD, Reiva Farah Dwiyana, MD, MSc, Srie 
Prihianti Gondokaryono, MD, PhD, Inne Arline Diana, MD. Wrote the paper: Hendra Gunawan, MD, PhD, Fitra Hergyana, MD, Catherina Jessica Sutantoyo,MD. Revised the article critically for important intellectual content: Hendra Gunawan, MD, PhD.

\section{CONFLICTS OF INTERESTS}

The author of this study declared no conflict of interest

\section{REFERENCES}

1. Leung MD, Eichenfield LF, Boguniewicz M. Atopic dermatitis. In: Goldsmith LA, Katz BA, Gilchrest BA, Paller AS, Leffel DJ, Wolff K. editors. Fitzpatrick's Dermatology in General Medicine. $8^{\text {th }}$ ed. New York: Mc Graw Hill; 2012. p. 165-82.

2. Diana IA, Boediardja SA, Sugito TL, Lokanata MD, Gondokaryono SP, Danarti $\mathrm{R}$, et al. Atopic dermatitis in indonesia. In: Diana IA, Boediardja SA, Sugito TL, Lokanata MD, Gondokaryono SP, Danarti R, et al. Guideline on diagnosis and treatment of atopic dermatitis in Indonesia. $1^{\text {st }}$ ed. Jakarta: Indonesia University Press; 2014. p. 1-3.

3. Reitamo S, Luger TA, Steinhoff M. The clinical manifestation of atopic dermatitis In: Reitamo S, Luger TA, Steinhoff M. editors. Textbook of atopic dermatitis. $1^{\text {st }}$ ed. England: CRC Press; 2008. p. 37-52.

4. Baumann L. Cosmetic and skin care in dermatology. In: Goldsmith LA, Katz BA, Gilchrest BA, Paller AS, Leffel DJ, Wolff K. editors. Fitzpatrick's dermatology in general medicine. $8^{\text {th }}$ edition. New York: McGraw-Hill; 2012. p. 3009-12.

5. Jensen JM, Holst RF, Baranowsky A, Schunck M, Morbach SW. Impaired sphingomyelinase activity and epidermal differentiation in atopic dermatitis. J Invest Dermatol 2004;122 Suppl 6:1423-31.

6. Willemsen MG, van Valburg RWC, Dirven Meijer PC, Oranje AP, der Wounden JC, Moed H. Determining the severity of atopic dermatitis in children presenting in general practice: an easy and fast method. Derm Res Practice 2009;1-5. http:// dx.doi.org/10.1155/2009/357046

7. Correa MCM, Nebus J. Management of the patient with atopic dermatitis: the role of emollient therapy. Dermatol Res Practice J 2012;1-15. Doi: 10.1155/2012/836931
8. Addor FAS, Aoki V. Skin barrier in atopic dermatitis. An Bras Dermatol J 2010;85:184-94.

9. Draelos ZD. Modern moisturizer myths, misconception, and truths. Cutis 2013;6:308-11.

10. Kircik LH, Del Rosso JQ. Nonsteroidal treatment of atopic dermatitis in pediatric patients with a ceramide-dominant topica emulsion formulated with an optimized ratio of physiological lipids. J Clin Aesthet Dermatol 2011;4:25-31.

11. Sonkamble VV, Wagh NS, Kamble LH. Inhibition of $\alpha$-amylase and $\alpha$-glucosidase by (6RS)-22-hydroxy-23,24,25,26,27pentanor-vitamin-d3-6,19-sulfur dioxide-adduct, manoalide and $5 \beta$-cholestane- $3 \alpha, 7 \alpha, 12 \alpha, 24,25,26$-hexol isolated from acetone extract of Helianthus annuus L. seeds. Int J Pharm Pharm Sci 2018;10 Suppl 5:39-49.

12. Eichenfield LF, McCollum A, Msika P. The benefits of sunflower oleodistilate (SOD) in pediatric dermatology. Ped Dermatol J 2009;26 Suppl 6:669-75.

13. Kraft L, Nitayavardhana S, Kultanan K. Moisturizers for patients with atopic dermatitis. Asian Pac J Allergy Immunol 2013;3:91-8.

14. Hatano Y. New insight into the pathogenesis of atopic dermatitis from analysis of the mutual association between permeability barrier dysfunction and allergic inflammation. Dermatol Sinic J 2015;33:74-7.

15. Danby SG, Al Enezi T, Sultan A, Lavender T, Chittock J, Brown K, et al. Effect of olive oil and sunflower seed oil on the adult skin barrier: implications for neonatal skin care. Ped Dermatol J 2012;30:42-50.

16. Darmstadt GL, Mao-Qiang M, Chi E, Saha SK, Ziboh VA, Black RE. Impact of topical oils on the skin barrier; possible role implications for neonatal health in developing countries. Acta Paediatr J 2002;5:546-54.

17. Jiraungkoorskul W. Review of nutraceutical uses of an antioxidant sunflower sprout, Helianthus annuus. Asian J Pharm Clin Res 2016;9 Suppl 6:21-3.

18. Dakhil IA, Abbas IA, Nidhal KM. Preparation, evaluation, and clinical application of safflower cream as a topical nutritive agent. Asian J Pharm Clin Res 2018;11 Suppl 8:495-7.

19. Husna N, Suryanto, Purba D. The effect of sunflower seed oil hand cream. J Pharmaceut Pharmacol 2012;1 Suppl 1:63-9. 